\title{
INVESTIGATING POST-WORK INTEGRATED LEARNING (WIL) EFFECTS ON MOTIVATION FOR LEARNING: AN EMPIRICAL EVIDENCE FROM MALAYSIAN PUBLIC UNIVERSITIES
}

\author{
Hazril Izwar Ibrahim* \\ Universiti Sains Malaysia \\ Amar Hisham Jaaffar \\ Universiti Sains Malaysia
}

\begin{abstract}
Work-integrated learning (WIL) is regarded as an important medium to assist development of student's relevant technical and non-technical competencies, knowledge and psychological attributes that can enhance their employability and learning outcomes. This study examines the relationship between the outcomes of WIL programs such as thinking and communication skills, self-efficacy and motivation for learning of 383 undergraduate in business degree from four Malaysian public universities who have participated on various WIL programs. Results show that student's motivation for learning is affected by student's thinking skills and mediated by student's self-efficacy. Interestingly, student's communication skills only influenced motivation for learning through the self-efficacy. The findings provide a valuables insight into the limited research pertaining to the sequel of the outcomes of WIL programs such as student's competencies, psychological attributes and specific learning outcomes.
\end{abstract}

Keywords: Work-Integrated Learning; Motivation for Learning; Self-Efficacy; Thinking Skills; Communication Skills.

\section{INTRODUCTION}

"Soaring upward" which mean continuous improvement is the current slogan of Ministry of Higher Education of Malaysia which serves as an inspiration for the ministry and stakeholders to move forward to boost the outcome of higher education and establishing values that will create holistic individuals out of their tertiary students (Yap, 2015). Increasing the level of interest and motivation among students is the priority of higher education providers (Heydarei \& Daneshi, 2015). It is essential to develop a better understanding of the factors and facets of academic motivation (Komarraju, Karau, \& Ramayah, 2007) because previous study revealed that student with learning motivation are better equipped with the learning strategies necessary to navigate through uncertainty and complexity (Dawson, Macfadyen, \& Lockyer, 2009). Furthermore, motivation can be regarded as one of the core critical skills for talent development (Subotnik, Olszewski-

*Corresponding author: Dr. Hazril Izwar Ibrahim, School of Management, Universiti Sains Malaysia, 11800 USM, Penang, Malaysia. Email:hazrili@yahoo.com 
Kubilius, \& Worrell, 2011). Researchers have long recognized the importance of motivation for academic success in Malaysia (e.g. Bakar et al. 2010; Chong \& Ahmed, 2012; Komarraju et al. 2007). In analyzing the nature of student's motivation for learning, psychologist and academics have moved away from a cognitive model towards a sociocognitive model (Bong, 1996; Linnenbrink \& Pintrich, 2002). The social-cognitive model implies that students are motivated in multiple ways, and that motivation is influenced by both extrinsic (social and cultural) and intrinsic (cognitive) factors (Cury, Elliot, Da Fonseca, \& Moller, 2006; Dweck \& Leggett, 1988). One of the extrinsic and intrinsic factors that lead to motivation for learning is through Work Integrated Learning (WIL) (Drysdale et al., 2007; Freudenberg, Brimble, \& Vyvyan, 2010; Friedman, Rodriguez, \& McComb, 2001; Litchfield, Frawley, \& Nettleton, 2010; Powell, Tindal, \& Millwood, 2008). WIL represents the intersection of theoretical and practical learning and is a distinguished aspect of interface between higher education providers and industry (Nagy \& Smith, 2016). WIL is often referred to as experiential learning; work-based learning; and cooperative education which exist in various types of activities including: 1) clientbased project; 2) internship; 3) placements; 4) fieldwork; and 5) practicum (Elijido-Ten \& Kloot, 2015; Nagy \& Smith, 2016; Rowe, Mackaway, \& Winchester-Seeto, 2012). The focal point of WIL is the enhancement of work-readiness and employability through developing student's non-technical competences (e.g. soft skills); psychological attributes (e.g. self-confidence, self-efficacy, and self-esteem); and learning outcomes (e.g. motivation for learning) (Drysdale et al., 2016).

It is well established by Freudenberg et al. (2010) and Lizzio and Wilson (2004) that WIL contributes to students improved personal skills and competencies such as decisionmaking skills, interpersonal and self-management skills; however, Purdie et al (2013) argue that the actual gains from WIL exceed the improvement in employability skills and competencies. The actual benefit of WIL is its effect on the university students' psychological attributes, as it allows them to be more adaptable in work and social environment. Thus, the impact of WIL on psychological developments confers the students with a more positive outlook which provides them with a confident attitude in gaining future employment (Allen \& Van der Velden, 2007). According to Cuzzi et al. (1996) and Crebert et al. (2004), one of the psychological domains which are synonymous with WIL is self-efficacy. Creed, Bloxsome, and Johnston (2001) citing Eden and Aviram (1993) and Phelps and Creed (1996) discovered significant improvement in self-efficacy levels after individuals attended training programs which were exhibited by their confident and positive behaviour in searching for re- employments. Similarly Raelin et al. (2011) found that participation in WIL results in improved self-efficacy among students. Edwards (2014) opines that improvement in students' self-efficacy, after participating in work placement programs, is demonstrated by their self-confidence in attending interviews and enunciating their skills and strengths.

This study focuses on the relationship between the outcomes of WIL programs such as student non-technical competences (e.g. thinking skills and communication skills); psychological attributes (e.g. self-efficacy); and learning outcomes (e.g. motivation for learning), since there has been a lack of sufficient research regarding to WIL's outcomes for nurturing graduate motivation for learning. From the perspective of Self Determination Theory, this study provides theoretical explanation regarding the sequence and relationship between the outcomes of WIL programs. This study also focus on the 
outcomes of learning activities from the higher education context since majority of the outcomes of learning activities were developed from the workplace or school setting (Chong \& Ahmed, 2012).Practically, this research is important in emerging economies like Malaysia where the level of educational achievement of its' citizen is viewed as a crucial factor for people's 'national interests' such as socio-economic development and nation-building (Kember, Hong, \& Ho, 2008; Nikitina \& Furuoka, 2012). Moreover this research is also consistent with the National Education Philosophy outlined in the Malaysian Education Development Blueprint's (2013-2025) which has given great emphasis on holistic development of studentsin line with quality human capital generation in accordance with Government Transformation Program (GTP) which drives Malaysia towards becoming a developed and high-income country (Rus et al., 2015). The psychological factor has long been overlooked in developing and enhancing university students' employability. The study proposes that the skills obtained during their internship/ industrial training should lead to improved self-efficacy, as prospective employers are interested in versatile graduates who are able to perform and function within the work environment.The main research objective of this study is to examine the relationship between thinking skills and communications skills; self-efficacy; and motivation for learning. Although the student non-technical competences not only consist of thinking skills and communication skills, this study choose those two skills as previous study has found that graduate in Malaysia were mostly lack in analytical thinking and communication abilities (World Bank, 2014).

\section{LITERATURE REVIEW}

Recently, the Higher Education Providers in Malaysia are increasingly initiating workintegrated learning (WIL) programs (Khalid et al., 2014; Maelah, Muhammaddun Mohamed, Ramli, \& Aman, 2014; Renganathan, Abdul Karim, \& Chong, 2012; Saat, Yusoff, \& Panatik, 2014). WIL has also been linked to higher institution providers' strategy to position and project themselves in the competitive international education market (Nagy \& Smith, 2016). In fact, the promotion of WIL has been regarded by several institutions and countries as being key to agenda to provide quality education (Tran \& Soejatminah, 2016). WIL is valued as it empowers personal learning in addition to professional learning and related to student's individual agency (Reay, 2004). WIL provides cultural and social capabilities which can be intertwined with academic skills which subsequently tends to manifest as student's individual agency with respect to student's motivation to learn (Edgerton \& Roberts, 2014; Lareau \& Weininger, 2003). Previous study has revealed the various outcomes of WIL programs to students including in term of career, academic, personal benefits (Dressler \& Keeling, 2011). However, there is a lack study which focuses on the relationship of these outcomes. It is importance to investigate the linkages between the outcomes of WIL, as this will provides academic and practical insight to the improvement of this learning activity.

\subsection{Motivation for Learning}

Learner's motivation can be described as their "state of cognitive and emotional arousal, which leads to aconscious decision to act, and which gives rise to a period of sustained intellectual and orphysical effort in order to attain a previously set goal (or goals)" 
(Williams \& Burden, 1997, p. 120). Learner's motivation relates to the desire to participate in the learning (Lumsden, 1994) and can be regarded as the most important aspects of education (Lumsden, 1999) as well as the fundamental aspect of academic achievement (Guay et al., 2010). Motivation for learning have been regarded as the most important aspects of life-long learning (McCombs, 1991). Studentswith high learning motivation will have strong autonomous motivation and self-regulation orientation which subsequently increase their continuous or lifelong learning; upward mobility; career development learning and employability (Jackson \& Wilton, 2016 ; Patton \& McMahon, 2014). Dresslerand Keeling (2004) revealed that competencies such as non-technical skills obtained from WIL programs have improved student's motivation for learning. While, self-efficacy which is also one of the outcomes of WIL programs (Oliver, 2015; Smith \& Worsfold, 2014; Yorra, 2014) have been regarded as important source of motivation (Bandura, 2011). This demonstrates that there are linkages between the outcomes of WIL programs with student's motivation for learning (Dressler and Keeling, 2004; Drysdale et. al. 2007; Freudenberg et al., 2010; Jackson, 2015; Jackson and Wilton, 2016; Kato and Hirose, 2008; Litchfield et al., 2010).

\subsection{Thinking Skills and Communication Skills}

Thinking skills and communication skills are among the component of non-technical attributes or competencies obtained from the WIL programs. This non-technical attributes or competencies are equivalent with soft skills which isdefined as the "interpersonal, human, people or behavioural skills needed to apply technical skill and knowledge in the workplace" (Weber, Finley, Crawford, \& Rivera, 2009). In relation to universities' graduates, soft skills are seen as being deficient relative to hard skills (Arnold \& Mackenzie Davey, 1994; Mullen, 1997). Likewise, soft skills are generally viewed as less important by academics in comparison with hard skills (Page, Wilson, \& Kolb, 1993). Soft skills include thinking skills; communication skills; management skills; computing skills; interpersonal skills; and entrepreneurship skills. Previous studies revealed that student who possesses soft skills will have competence-related belief which influence their motivation for leaning (Guthrie, Wigfield, Metsala, \& Cox, 1999). Previous research revealed that WIL is widely considered as an instrument in equipping students with the required soft skills (e.g. Jackson, 2015; Khalid et al. 2014; Maelah et. 2014; Tran \& Soejatminah, 2016). With respect to thinking skills, critical thinking or higher-order cognitive skills enables student to participate actively in knowledge development and to become independent lifelong learners (Maclellan, 2004; Tsui, 2002). The development of thinking skills has long been regarded to be the core outcome of education and a stated objective of higher education (Tsui, 2002). According to Jackson and Chapman (2012), thinking skills involve the behaviour of student to 1) conceptualize (recognize patterns in detailed documents and scenarios to understand the "bigger" picture and evaluation of certain matters) and 2) evaluation (recognize, evaluate and retain key point in a range of document and scenarios). Student are usually lacking in thinking skills due to lack of time, opportunity support and resources for developing this skills (Jackson, 2015).

Communication skills grant student with the ability to convey their needs more effectively and equip them with the competence to understand the needs of others (Vatankhah, Daryabari, Ghadami, \& Naderifar, 2013).Jackson and Chapman (2012) portrayed that communication skills include: 1) verbal communication; 2) giving and receiving 
feedback; 3) public speaking and; 4) written communication. Previous research from Malaysia demonstrated student improved their communication skills after participating in WIL program (Cheong, Yahya, Shen, \& Yen, 2014; Khalid et al., 2014; Maelah et al., 2014). Nevertheless, Jackson's (2015) survey of 131 undergraduates across different disciplines in an Australian university found that students experienced difficulties in acquiring communication skills in their WIL program including articulating their viewpoint, instructions and responses to different audiences in the workplace and sometimes struggled to engage others and make their voices heard.

\subsection{Self-Efficacy}

In accordance with Bandura (1990, 2011), self-efficacy refers to one's beliefs in his or her ability to organize and execute the courses of action that are required to produce given attainments. Self-efficacy includes the belief that one is able to do something and that by doing so one can achieve a desired outcome which influences an individual's general perceived level of competence which latterly affects motivation and learning especially in academic and work domain (Gore, 2006). Self-efficacy in the academic sphere can be distinguished as an individual's belief in their ability to successfully perform academic tasks (Schunk, 1991). There is an increasing body of research that indicates that measures of academic self-efficacy are predictive of students' academic achievement (Zajacova, Lynch, \& Espenshade, 2005). High self-efficacy beliefs are also associated with the use of learning strategies (DiBenedetto \& Zimmerman, 2010). Moreover, self-efficacy is related to high academic performance and the use of self-regulatory strategies (Bembenutty, 2011).

\subsection{Theoretical Framework of the Study}

This research uses Self-Determination Theory (SDT) (Deci \& Ryan, 2000; Ryan \& Deci, 2000) to elucidate the relationship between the outcomes of WIL programs since the outcome of higher education has been concerned with students capacity for autonomous action (McLachlan \& Hagger, 2010). Furthermore, past studies related to student's engagement have also utilized SDT (Schuetz, 2008). SDT regards human as innately motivated to learn and developed as long as the social contextual conditions provides for the individual's basic psychological needs such as autonomy, competence, and relatedness (Deci \& Ryan, 2000; Ryan \& Deci, 2000). The need for autonomy refers to the need to feel a sense of full volition and "choicefulness" pertaining to one's activities and goals, a feeling that develops when action and goals are experienced when actions and goals are experienced as originating from one's authentic self. The need for competence is the need to be effective in one's interactions with the environment, and to feel that one is capable of mastering challenges. The need for relatedness refers to the need to feel closely related to other people (Deci \& Ryan, 2000; Ryan \& Deci, 2000).

SDT also proposes a wider distinction between intrinsic and extrinsic motivation, which is particularly pertinent to the need for autonomy, or desire to experience behaviour as self-initiated and self-regulated (Deci \& Ryan, 2000). Intrinsic motivation refers to doing something because it is innately interesting, while, extrinsic motivation refers to doing something because it leads to a separate desired outcome (Ryan \& Deci, 2000). From the perspective of WIL, this theory provides explanation regarding the supportive social 
environment in WIL activities such as in practicum, fieldwork, placements, internship and client-based project which can promote student feeling of competence or self-efficacy (Zepke, 2011). Such feeling in turn encourages the exercise of self-direction leading to greater feeling of autonomy. Previous studies revealed that the more individual's motivation is autonomous, the better the prospect for the quality of learning persistence, and affective experience to be enhanced (Niemiec \& Ryan, 2009). In this study, SDT provides the explanation regarding to the relationship of perceived non-technical competence of student which participated in WIL programs (e.g. thinking skills and communication skills), psychological attributes (e.g. self-efficacy), and motivation for learning. The research framework (see Figure 1) of the study has been developed based on the perspectives of SDT exhibiting the relationship between autonomous, competent and relatedness.

Figure 1: Proposed Framework

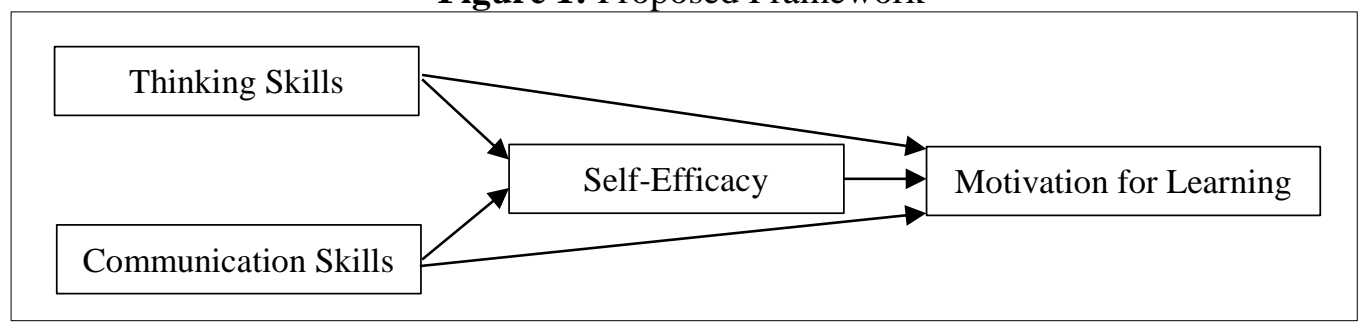

\subsection{Hypotheses Development}

Based on Self Determination Theory (SDT) (Deci \& Ryan, 2000; Ryan \& Deci, 2000), student's which participated in WIL programmes innately motivated to learn and developed as long as the social contextual conditions of WIL programmes provides for the student's basic psychological needs such as autonomy, competence and relatedness. SDT posits that the student's motivation for learning has relationship with student's psychological attributes and perceived competence. WIL provided opportunity for student to develop their thinking skills through the discussion of ideas and advice from the professionals (Jackson, 2013). Critical thinking skills has been identified as the one of the important element in student's motivation for learning (Bembenutty, 2011) and increased student's self-efficacy (Bandura,1990). Thus, this study suggests these hypotheses:

H1: Student's thinking skills affects the student's self-efficacy.

$H 2$ : Student's thinking skills affects the student's motivation for learning.

Previous research revealed that student which participated in WIL programmes has improved their communication skills (Cheong et al., 2014; Khalid et al., 2014; Maelah et al., 2014). Communication skills are associated positively with self-efficacy (Hommes \& Van der Molen, 2012; Martin \& Myers, 2006). Furthermore, previous study also demonstrated that communication skills lead to motivation for learning (Webster, 2010).Thus, this study suggests these hypotheses:

H3: Student's communication skills affect the student's self-efficacy.

H4: Student's communication skills affect the student's motivation for learning. 
Previous studies demonstrated that student increases their self-efficacy as a result of WIL programs (Oliver, 2015; Smith \& Worsfold, 2014; Yorra, 2014). Self-efficacy can be regarded as an important source of motivation for learning (Guthrie \& Humenick, 2004; Lin, Wong, \& McBride-Chang, 2012; Schiefele, Schaffner, Möller, \& Wigfield, 2012). Furthermore, undergraduates with high self-efficacy were more likely to rate themselves higher in soft skills' ability particularly in communication and thinking ability (Direito, Pereira, \& de Oliveira Duarte, 2012). Thus, this study suggests these hypotheses:

H5: Student's self-efficacy affects the student's motivation for learning.

H6: Student's thinking skills indirectly affect the student's motivation for learning through student's self-efficacy.

H7: Student's communication skills indirectly affect the student's motivation for learning through the student's self-efficacy.

\section{RESEARCH METHODOLOGY}

The unit of analysis of this study comprised of individuals which consist of undergraduates in business degree students of Malaysian Public University who have undergone training programmes for six months including: 1) Internship/Placement/Practicum; 2) Industry Attachment; 3) Research Assistantship (paid/unpaid); 4) Teaching Assistantship; 5) Job Shadowing; 6) Volunteering (community service); and 7) Study Abroad. This study involved a sample 383 respondents which consist of students who have undergone industrial training in various organizations in Malaysia. The instrument used was a self-administered questionnaire. The data were collected through purposive sampling method as it targets specific group of respondents. 500 questionnaires were distributed to student from four public universities in Malaysia with 383 surveys returned indicating $76.6 \%$ rate of return. The usable questionnaires recorded in this study meet the rule of thumb where the minimum number of respondent is 10 to 1 ratio of latent variables to be tested (Chin, 1998; Hair, Ringle, \& Sarstedt, 2011). SmartPLS 2.0 software was used to evaluate the relationship among the constructs of the research model by conducting partial least square (PLS) analysis. The analysis was analysed by following the guidelines of Hair, Hult, Ringle, and Sarstedt (2013) in reporting the Partial Least Square-Structural Equation Modeling (PLS-SEM) approach.

\subsection{Scales of Measurement}

The measurement items used for the questionnaire were identified from previous literature. Thinking skills and communication skills were adopted from (Abdul Hamid, Islam, \& Abd Manaf, 2014). Critical thinking skills contains eight items and measured using five point responses ranging from strongly disagree to strongly agree. Communications skills contain eleven items and measured using five point responses ranging from strongly disagree to strongly agree. The general self-efficacy scale was adopted from Chen, Gully, and Eden (2001), it is composed of eight items and measured using five-point response scale, ranging from strongly disagree to strongly agree. The motivation for learning scale was adapted from Tuan, Chin, and Shieh (2005). Motivation learning for learning contains seven items and measured using five points responses ranging from strongly disagree to strongly agree. 


\section{RESULTS}

\subsection{Respondent Profiles}

As illustrated in Table 1, 89 respondents were male (23.2\%) and 294 were female (76.8\%). A total of 370 (96.6\%) of respondents have undergone Internship/Placement/Practicum; 26 (6.8\%) Industry Attachment Industry Attachment; 8 (2.1\%) have undergone Research Assistantship (paid/unpaid); 12 (3.15) have undergone Teaching Assistantship; 4 (1\%) have undergone Job Shadowing; 61 (15.9\%) have undergone Volunteering (community service) and 7 (1.8\%) have undergone Study Abroad. The percentage of male and female students in this study reflects the scenario in public universities in Malaysia, where, generally the percentage for female students is higher than male students based on the statistics released in the Indicator for Higher Education Report 2009-2013(Ministry of Higher Education, 2013). The huge percentage of female student in this study is consistent with study of higher education learning in Malaysia such as Embi and Nordin (2013) which posited the huge percentage (more than 70 percent) of female students in Malaysian higher education institution. The current study's definition of WIL activities is consistent with the definition of WIL by Martin et al. (2012) which includeswork-based learning, work-related learning, industry-related learning, work-based project, industry project, industry experience, work experience, practicum, co-operative education, practicum, sandwich course, internship, or placement.

Table 1: Descriptive Statistics

\begin{tabular}{|c|c|c|c|c|}
\hline \multicolumn{2}{|l|}{ Description } & Frequency & \multicolumn{2}{|c|}{ Percentage } \\
\hline \multicolumn{5}{|l|}{ Gender } \\
\hline \multicolumn{2}{|l|}{ Male } & 89 & & 23.2 \\
\hline \multicolumn{2}{|l|}{ Female } & 294 & & 76.8 \\
\hline \multicolumn{5}{|l|}{ Training Programmes Involved } \\
\hline \multicolumn{2}{|l|}{ Internship/Placement/Practicum } & 370 & & 96.6 \\
\hline \multicolumn{2}{|l|}{ Industry Attachment } & 26 & & 6.8 \\
\hline \multicolumn{2}{|c|}{ Research Assistantship (paid/unpaid) } & 8 & & 2.1 \\
\hline \multicolumn{2}{|l|}{ Teaching Assistantship } & 12 & & 3.1 \\
\hline \multicolumn{2}{|l|}{ Job Shadowing } & 4 & & 1.0 \\
\hline \multicolumn{2}{|c|}{ Volunteering (community service) } & 61 & & 15.9 \\
\hline \multicolumn{2}{|c|}{ Study abroad } & 7 & & 1.8 \\
\hline Respondent's Profile $(\mathrm{N}=383)$ & Mean & Standard Deviation & Minimum & Maximum \\
\hline Motivation for learning & 4.18 & 0.552 & 2 & 5 \\
\hline Communication Skills & 3.82 & 0.761 & 1 & 5 \\
\hline Thinking Skills & 3.94 & 0.62 & 1 & 5 \\
\hline
\end{tabular}

\subsection{Measurement Model}

Partial least squares-based structural equation modelling (PLS-SEM) was applied to analyse the data using SmartPLS (Ringle, Wende, \& Will, 2005). The PLS path modelling technique was chosen due to its accommodation of independent distribution, this being a suitable technique for a complex model and for testing a theoretical model with mediation and moderation relationships (Hair et al., 2013; Zhao, Lynch, \& Chen, 2010). The theoretical model was assessed in a two-step process. First we assessed the measurement 
model and then we assessed the structural model (Chin, 2010; Hair et al., 2011; Hair, Sarstedt, Ringle, \& Mena, 2012). In assessing the measurement model, we examined the validity and reliability of the relationships between the latent variables (LV) and any associated observable variables.

Table 2: Measurement Model

\begin{tabular}{|c|c|c|c|c|}
\hline Measures & Item & Factor Loading & AVEb & $\overline{\mathbf{C R}}$ \\
\hline Motivation For & MOV 1 & 0.6886 & \multirow{7}{*}{0.5640} & \multirow{7}{*}{0.9000} \\
\hline \multirow[t]{6}{*}{ Learning } & MOV 2 & 0.7395 & & \\
\hline & MOV 3 & 0.7982 & & \\
\hline & MOV 4 & 0.7537 & & \\
\hline & MOV 5 & 0.7379 & & \\
\hline & MOV 6 & 0.7546 & & \\
\hline & MOV 7 & 0.7811 & & \\
\hline \multirow[t]{8}{*}{ Self-Efficacy } & EFF 1 & 0.7332 & \multirow{8}{*}{0.5730} & \multirow{8}{*}{0.9150} \\
\hline & EFF 2 & 0.8042 & & \\
\hline & EFF 3 & 0.6708 & & \\
\hline & EFF 4 & 0.7489 & & \\
\hline & EFF 5 & 0.7843 & & \\
\hline & EFF 6 & 0.7827 & & \\
\hline & EFF 7 & 0.7615 & & \\
\hline & EFF 8 & 0.7646 & & \\
\hline \multirow[t]{5}{*}{ Communication Skills } & CMS 1 & 0.7742 & \multirow{5}{*}{0.512} & \multirow{5}{*}{0.839} \\
\hline & CMS 2 & 0.7586 & & \\
\hline & CMS 7 & 0.5964 & & \\
\hline & CMS 10 & 0.6530 & & \\
\hline & CMS 11 & 0.7771 & & \\
\hline \multirow[t]{8}{*}{ Thinking Skills } & TS 1 & 0.7228 & \multirow{8}{*}{0.514} & \multirow{8}{*}{0.893} \\
\hline & TS 2 & 0.7054 & & \\
\hline & TS 3 & 0.7129 & & \\
\hline & TS 4 & 0.7964 & & \\
\hline & TS 5 & 0.6667 & & \\
\hline & TS 6 & 0.5824 & & \\
\hline & TS 7 & 0.7309 & & \\
\hline & TS 8 & 0.7941 & & \\
\hline
\end{tabular}

Notes:CMS3, CMS4, CMS5, CMS6, CMS8, and CMS9 were deleted due to low loadingCR = composite reliability; $\mathrm{AVE}=$ average variance extracted.

In assessing the structural model, we account for the relationships between the theoretical construct (Chin, 2010; Hair et al., 2011). The measurement model was evaluated by examining the reliability of the individual items, internal consistency or construct reliability, average variance extracted (AVE) analysis, and discriminant validity. A measurement model has satisfactory internal consistency reliability when the composite reliability (CR) of each construct exceeds the threshold value of 0.7 (Hair et al., 2011; Hulland, 1999); the latent variable values higher than 0.5 for convergent validity (Bagozzi \& Yi, 1988; Chin, 2010; Hair et al., 2011); and have satisfactory indicator reliability when 
the loading of each items is at least 0.4 or higher for exploratory research and is significant at least at the level of 0.05 (Hulland, 1999). Based on Table 2, generally the items in the measurement model exhibited loading that exceed 0.5824 ranging from a lower bound of 0.5824 to an upper bound of 0.8042 . The CR values for all construct are more than 0.839 , while the AVE values for all constructs were higher than 0.5 . Thus, based on Table 2, all the items used for this study have demonstrated satisfactory indicator reliability.

\subsection{Discriminant Validity}

Discriminant validity describes the extent to which each construct is distinct from one another (Chin, 1998). Two measures must be checked to test discriminant validity. The AVE of each construct should be higher than the highest squared correlation of the construct with any other LV in the model, and the loading of an indicators with its associated LV must be higher than its loading with other LVs (Chin, 2010; Fornell \& Larcker, 1981; Hair et al., 2011).Thus, to determine the first assessment of the measurement model's discriminant validity, the AVE value of each construct is generated using the SmartPLS algorithm function. Then, the square roots of the AVE are calculated manually. Based on the results, all the square roots of the AVE exceeded the off-diagonal elements in their corresponding row and column. The bolded elements in Table 4 represent the square roots of the AVE and the non-bolded values represent the intercorrelation value between the constructs. Based on Table 3, all the off-diagonal elements are lower than the square roots of the AVE (bolded on the diagonal). Hence, the results confirmed that the Fornell and Larcker's criterion is met.

Table 3: Discriminant Validity

\begin{tabular}{ccccc}
\hline \hline & CMS & EFF & MOV & TS \\
\hline CMS & $\mathbf{0 . 7 1 5 5}$ & & & \\
EFF & 0.5858 & $\mathbf{0 . 7 5 6 9}$ & & \\
MOV & 0.4729 & 0.5473 & $\mathbf{0 . 7 5 0 9}$ & \\
TS & 0.6683 & 0.5719 & 0.5025 & $\mathbf{0 . 7 1 6 9}$ \\
\hline
\end{tabular}

Note: Average variances extracted (AVEs) are shown (in bold) on diagonal.

In addition to evaluating the magnitude of the $\mathrm{R}^{2}$ values as a criterion of predictive accuracy, we also examined Stone-Geisser's Test to measure the indicator of the model's predictive relevance (Geisser, 1974; Stone, 1974). According to Hair et al. (2014), "PLSSEM exhibits predictive relevance, it can accurately predict the data points of indicators in reflective measurement models of endogenous construct and endogenous single-item constructs" (p. 178). We conducted predictive relevance or $\mathrm{Q}^{2}$ analysis using blindfolding procedure. Blindfolding is a measure which builds on a sample re-use technique, which omits a part of the data matrix, estimates the model parameters and predicts the omitted part using the estimates (Hairet al. 2014). If the $\mathrm{Q}^{2}$ value is larger than 0 , we can conclude that the model has sufficient predictive relevance (Fornell \& Cha, 1994). The $\mathrm{Q}^{2}$ was 0.1974 , which was greater than 0 , thus predictive relevance was confirmed. 


\subsection{Structural Model}

The following subsections discuss the tests used to assess the validity of the structural model for this study. The validity of the structural model is assessed using the coefficient of determination $\left(R^{2}\right)$ and path coefficients. In addition, thisstudy also assesses the mediation relationships that are beingproposed in the research model. The coefficient of determination, $\mathrm{R}^{2}$ indicates the amount of variance in the dependent variables that is explained by the independent variables. Based on Figure 2, the coefficient of determination, $\mathrm{R}^{2}$ is 0.355 for the MOV endogenous latent variable. This means that the three latent variables (TS, CMS and EFF) moderately explain $35.5 \%$ of the variance in MOV. While TS and CMS together explain 39.2\% of the variance of EFF. Based on the Figure 2 also, the inner model suggests that EFF (0.366), followed by TS (0.246) and CMS (0.071). Thus, a larger $R^{2}$ value increases the predictive ability of the structural model. In this study, the SmartPLS algorithm function is used to obtain the $R^{2}$ values, while the SmartPLS bootstrapping function is used to generate the $t$-statistics values. For this study, the bootstrapping function generated 5000 samples from 383 cases. The results of the structural model are presented in Figure 3.

Figure 2: Path Coefficients of Motivation for Learning, Self-Efficacy, Thinking Skills, and Communication Skills

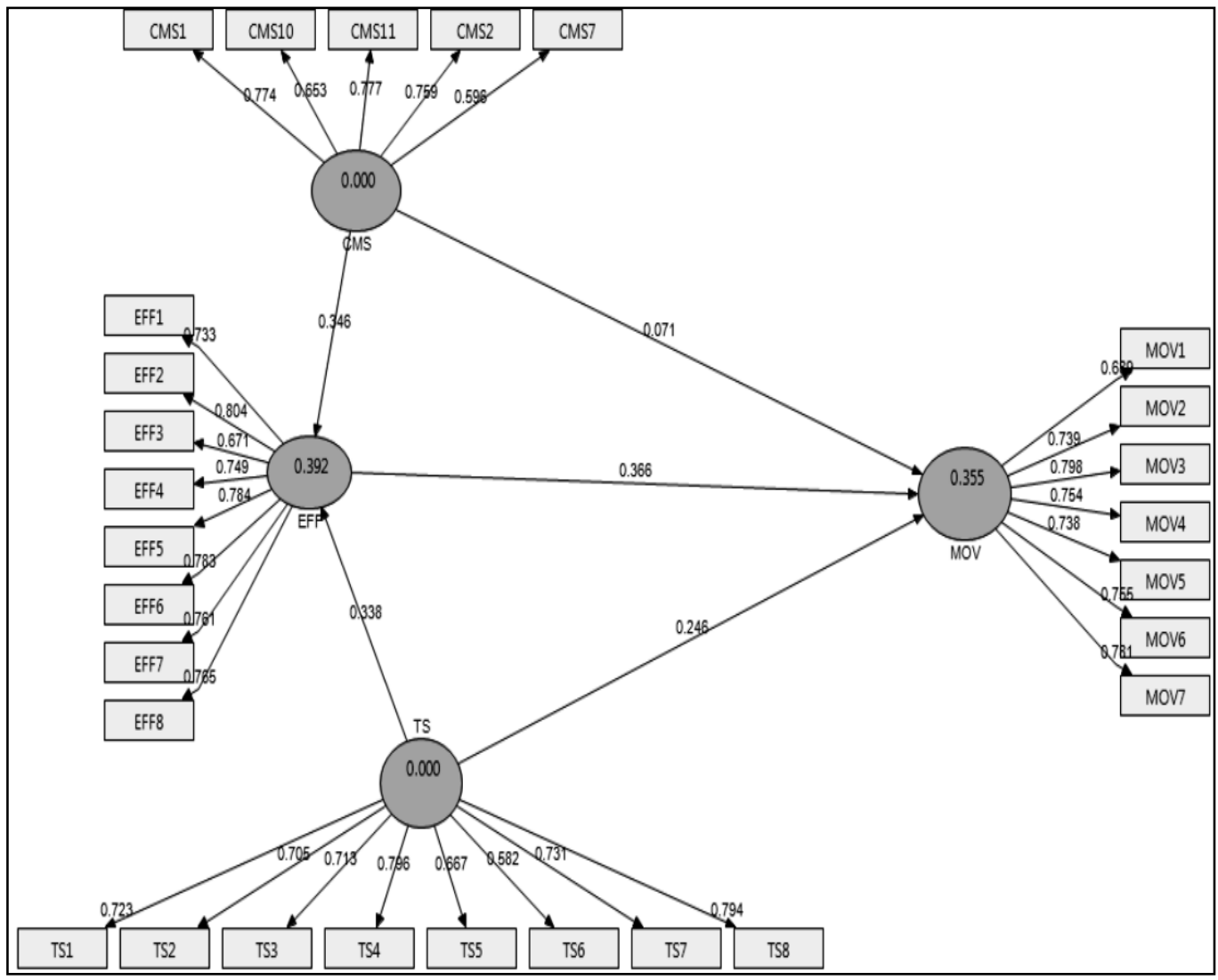


Figure 3: Bootstrapping of Path Coefficients of Motivation for learning, Self-Efficacy, Communication Skills and Thinking Skill

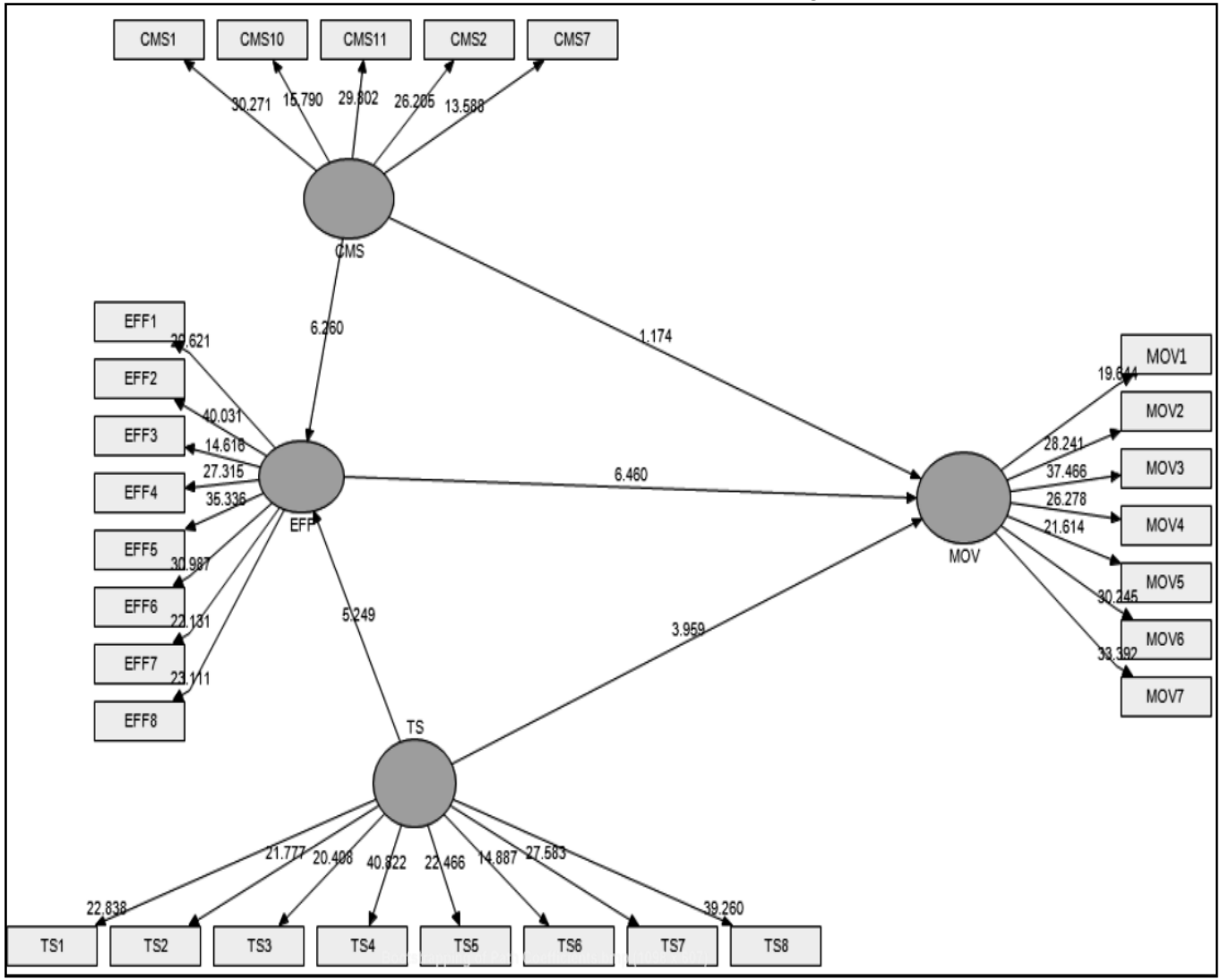

Table 4: Hypothesis Testing

\begin{tabular}{lcc}
\hline \hline \multirow{2}{*}{ Hypotheses } & \multicolumn{2}{c}{ Dependent = MOV } \\
\cline { 2 - 3 } & $\begin{array}{c}\text { Standard } \\
\text { Beta }\end{array}$ & Decision \\
\hline H1-TS positively affects EFF & $0.3378^{* * *}$ & Supported \\
H2 - TS positively affects MOV & $0.2455^{* * *}$ & Supported \\
H3 - CMS positively affects EFF & $630.3465^{* * *}$ & Supported \\
H4 - CMS positively affects MOV & 0.0708 & Not Supported \\
H5 - EFF positively affects MOV & $0.3658^{* * *}$ & Supported \\
H6- EFF mediate the relationship between TS and MOV & $0.12^{* * *}$ & Supported \\
H7 - EFF mediate the relationship between CMS and MOV & 0.02 & Not Supported \\
\hline $\mathrm{R}^{2}$ & 0.355 & \\
$\mathrm{R}^{2}$ Change & 0.11 & \\
\hline \hline
\end{tabular}

Notes: $* * * \mathrm{p}<0.01, * * \mathrm{p}<0.05,{ }^{*} \mathrm{p}<0.1$ 
From Table 4 , TS $\rightarrow$ EFF $(B=.3378, p<.01)$ and $\mathrm{CMS} \rightarrow \mathrm{EFF}(\beta=.3465, p<.01)$ were positively related to EFF with $\mathrm{R}^{2}$ of 0.392 indicating that $39.2 \%$ of the variance in EFF can be explained by the two construct. Hence $\mathrm{H} 1$ and $\mathrm{H} 3$ are supported. $\mathrm{EFF} \rightarrow \mathrm{MOV}$ ( $=.3658, p<.01)$ and $\mathrm{TS} \rightarrow \mathrm{MOV}(B=.2455, p<.01)$ were positively related to, whereas $\mathrm{CMS} \rightarrow \mathrm{MOV}(\beta=.0708, p>.01)$ was not significant. Thus, H2, H5, were supported, whereas H4 was not supported. Next, we ran a bootstrapping procedure with 5000 resamples and calculated the standard errors. The calculation led to the results as presented in Table 4. The bootstrapping analysis showed that the indirect effect of $\beta=0.12$ was significant with a $t$ value of 4.76 (TS $\rightarrow \mathrm{EFF} \rightarrow \mathrm{MOV}$ ) and the indirect effect of $\beta=0.02$ was insignificant with a $t$ value of 1.12 (CMS $\rightarrow \mathrm{EFF} \rightarrow \mathrm{MOV})$. In addition, as indicated by Preacher and Hayes (2008), the indirect effect of $0.12,95 \%$ boot confidence interval $(\mathrm{CI}):[0.073,0.1747](\mathrm{TS} \rightarrow \mathrm{EFF} \rightarrow \mathrm{MOV})$ do not straddle a 0 in between indicating there is mediation. Whereas, the indirect effect of $0.02,95 \%$ boot confidence interval (CI): [$0.0186,0.0677](\mathrm{CMS} \rightarrow \mathrm{EFF} \rightarrow \mathrm{MOV})$ straddle a 0 in between indicating there is no mediation. Thus H6 is supported and $\mathrm{H} 7$ otherwise.

\section{DISCUSSION AND CONCLUSION}

Results from descriptive statistic show that majority of the respondents have undergone WIL programs which subject to internship, placement, and practicum. This is in line with previous study on WIL programs in Malaysia which generally focused on undergraduate's industrial internship programs (Maelah et al., 2014; Renganathan et al., 2012; Saat et al., 2014). While, based on the result derived from structural model, this study found that motivation for learning is affected by thinking skills and mediated by self-esteem. This finding is consistent with Wang and $\mathrm{Wu}$ (2008) and Kickul, Gundry, Barbosa, and Whitcanack (2009) which posited that thinking skills are closely associated with selfefficacy. Furthermore this results also support Bandura's (2011) argument that selfefficacy beliefs are an important source of motivation. This result confirms that through WIL, students can observe and engage with other professionals which lead to the enhancement of their critical thinking competencies. This will increase their self-efficacy and subsequently increase their motivation to learn. Interestingly, communication skills only influence motivation for learning through the self-efficacy. This result supports the finding of past studies such as Hommes \& Van der Molen (2012) and Martin \& Myers (2006). The non- significant result of student's communication skills and motivation for learning may be due to the difficulties that students faced in articulating their viewpoint, instructions and responses to different audiencies in the work place and sometimes struggled to engage others and make their voices heard. This factors may hamper student's motivation for learning.

The finding provides a valuable insight into the government, higher education providers, and practitioners in developing strategies pertaining to the best practices in WILs environment for boosting the higher education outcomes. This study bring some valuable contributions with regard to the relationship between the outcomes of WIL programs to students particularly with regards to student's non-technical competences (e.g. soft skills); psychological attributes (e.g. self-confidence, self-efficacy, and self-esteem); and learning outcomes (e.g. motivation for learning). Through the lenses of SDT, this study shows that perceived competence of student regarding to their thinking and communication abilities 
increase their self-efficacy which in turn encourages motivation for learning. This study also shows that student's self-efficacy acts as mediating factor for the relationships between perceived competence of student in thinking and communication abilities and their motivation for learning. Hence, the designs of WIL's model which concerned with the condition that support the student's innate propensities to be autonomous, competent, and relatedness will impels a student's self-direction in learning process which in turn increase student's academic achievement as well as university's achievements.Despite the useful findings, this study has its own limitations as it only concentrates on undergraduate in business degree programs from four Malaysian public universities, therefore, it cannot be generalized to all university students in Malaysia. This study suggests that future research should be conducted to student from the sciences and engineering courses. Moreover, future research should also examine other student non-technical competences (e.g. management skill, interpersonal skills, computing skills, and entrepreneurship skills) and psychological attributes (e.g. self-esteem and self-confidence) obtain from various WIL programs.

\section{ACKNOWLEDGEMENT}

The authors wish to thank Universiti Sains Malaysia for financial support under Fundamental Research Grant Scheme No. 203/PMGT/6711447.

\section{REFERENCES}

Abdul Hamid, M. S., Islam, R., \& Abd Manaf, N. H. (2014). Employability Skills Development Approaches: An Application of the Analytic Network Process. Asian Academy of Management Journal, 19(1), 93-111.

Allen, J., \& Van der Velden, R. (2007). Transitions from higher education to work. In U. Teichler (Eds.), Careers of university graduates. Views and experiences in comparative perspectives (pp. 55-78). Dordrecht: Springer.

Arnold, J., \& Mackenzie Davey, K. (1994). Evaluating graduate development: key findings from the graduate development project. Leadership \& Organization Development Journal, 15(8), 9-15.

Bagozzi, R. P., \& Yi, Y. (1988). On the evaluation of structural equation models. Journal of the Academy of Marketing Science, 16(1), 74-94.

Bakar, K. A., Tarmizi, R. A., Mahyuddin, R., Elias, H., Luan, W. S., \& Ayub, A. F. M. (2010). Relationships between university students' achievement motivation, attitude and academic performance in Malaysia. Procedia-Social and Behavioral Sciences, 2(2), 4906-4910.

Bandura, A. (1990). Perceived self-efficacy in the exercise of personal agency. Journal of applied sport psychology, 2(2), 128-163.

Bandura, A. (2011). A social cognitive perspective on positive psychology. Revista de Psicología Social, 26(1), 7-20.

Bembenutty, H. (2011). Meaningful and maladaptive homework practices: The role of self-efficacy and self-regulation. Journal of Advanced academics, 22(3), 448-473. 
Bong, M. (1996). Problems in academic motivation research and advantages and disadvantages of their solutions. Contemporary Educational Psychology, 21(2), 149-165.

Chen, G., Gully, S. M., \& Eden, D. (2001). Validation of a new general self-efficacy scale. Organizational research methods, 4(1), 62-83.

Cheong, A. L. H., Yahya, N., Shen, Q. L., \& Yen, A. Y. (2014). Internship Experience: An In-Depth Interview among Interns at a Business School of a Malaysian Private Higher Learning Institution. Procedia-Social and Behavioral Sciences, 123, 333-343.

Chin, W. W. (1998). The partial least squares approach to structural equation modeling. Modern methods for business research, 295(2), 295-336.

Chin, W. W. (2010). How to write up and report PLS analyses. In V. Esposito Vinzi, W. W. Chin, J. Henseler \& H. Wang (Eds.), Handbook of partial least squares (pp. 655-690). Heidelberg, Berlin: Springer.

Chong, Y. S., \& Ahmed, P. K. (2012). Understanding Student Motivation in Higher Education Participation: A Psychometric Validation of the Academic Motivation Scale in the Malaysian Context. International Proceedings of Economics Development and Research, 53, 118-122.

Crebert, G., Bates, M., Bell, B., Patrick, C. J., \& Cragnolini, V. (2004). Developing generic skills at university, during work placement and in employment: graduates' perceptions. Higher Education Research \& Development, 23(2), 147-165.

Creed, P. A., Bloxsome, T. D., \& Johnston, K. (2001). Self-esteem and self-efficacy outcomes for unemployed individuals attending occupational skills training programs. Community, Work \& Family, 4(3), 285-303.

Cury, F., Elliot, A. J., Da Fonseca, D., \& Moller, A. C. (2006). The social-cognitive model of achievement motivation and the $2 \times 2$ achievement goal framework. Journal of personality and social psychology, 90(4), 666.

Cuzzi, L., Holden, G., Rutter, S., Rosenberg, G., \& Chernack, P. (1996). A pilot study of fieldwork rotations vs. year long placements for social work students in a public hospital. Social Work in Health Care, 24(1-2), 73-91.

Dawson, S. P., Macfadyen, L., \& Lockyer, L. (2009). Learning or performance: Predicting drivers of student motivation. In R. Atkinson \& C. McBeath (Eds.), Ascilite 2009: Same places, different spaces (pp. 184-193). Auckland, NZ: Ascilite.

Deci, E., \& Ryan, R. (2000). What is the self in self-directed learning? Findings from recent motivational research. In G. A. Straka (Eds.), Conceptions of self-directed learning: Theoretical and conceptual considerations. Münster, Germany: Waxmann.

DiBenedetto, M., \& Zimmerman, B. (2010). Differences in self-regulatory processes among students studying science: A microanalytic investigation. The International Journal of Educational and Psychological Assessment, 5, 2-24.

Direito, I., Pereira, A., \& de Oliveira Duarte, A. M. (2012). Engineering undergraduates' perceptions of soft skills: relations with self-efficacy and learning styles. ProcediaSocial and Behavioral Sciences, 55, 843-851.

Dressler, S., \& Keeling, A. (2004). Student benefits of cooperative education. In R. K. Coll \& C. Eames (Eds.), International handbook for cooperative education: An education (pp. 217-236). Boston, MA: World Association for Cooperative Education (WACE).

Dressler, S., \& Keeling, A. (2011). Benefits of cooperative and work-integrated education for students. In R. K. Coll \& K. E. Zegwaard (Eds.), International handbook for 
cooperative and work-integrated education: International perspectives of theory, research and practice ( $2^{\text {nd }}$ Ed., pp. 261-275). Lowell, MA: World Association for Cooperative Education (WACE).

Drysdale, M., Goyder, J., Nosko, A., Easton, M., Frank, K., \& Rowe, P. (2007). The role of co-op in the transition from high school to post-secondary education. Journal of Cooperative Education and Internships, 41(1), 48-55.

Drysdale, M., McBeath, M. L., Johansson, K., Dressler, S., Zaitseva, E., Helyer, R., \& Helyer, R. (2016). Psychological attributes and work-integrated learning: An international study. Higher Education, Skills and Work-Based Learning, 6(1), 20-34.

Dweck, C. S., \& Leggett, E. L. (1988). A social-cognitive approach to motivation and personality. Psychological review, 95(2), 256-273.

Eden, D., \& Aviram, A. (1993). Self-efficacy training to speed reemployment: Helping people to help themselves. Journal of applied psychology, 78(3), 352-360.

Edgerton, J. D., \& Roberts, L. W. (2014). Cultural capital or habitus? Bourdieu and beyond in the explanation of enduring educational inequality. Theory and Research in Education, 12(2), 193-220.

Edwards, M. (2014). The impact of placements on students' self-efficacy. Higher Education, Skills and Work-based Learning, 4(3), 228-241.

Elijido-Ten, E., \& Kloot, L. (2015). Experiential learning in accounting work-integrated learning: a three-way partnership. Education+ Training, 57(2), 204-218.

Embi, M. A., \& Nordin, N. M. (2013). Mobile learning: Malaysian initiatives \& research findings. Malaysia: Centre for Academic Advancement, Universiti Kebangsaan Malaysia.

Fornell, C., \& Cha, J. (1994). Partial least squares.In R. P. Bagozzi (Eds.), Advanced Methods of Marketing Research (pp. 52-78).Cambridge, MA: Blackwell Business.

Fornell, C., \& Larcker, D. F. (1981). Evaluating structural equation models with unobservable variables and measurement error. Journal of Marketing Research, 18(1), 39-50.

Freudenberg, B., Brimble, M., \& Vyvyan, V. (2010). The penny drops: can work integrated learning improve students' learning? eJournal of Business Education \& Scholarship of Teaching, 4(1), 42-61.

Friedman, P., Rodriguez, F., \& McComb, J. (2001). Why students do and do not attend classes: Myths and realities. College Teaching, 49(4), 124-133.

Geisser, S. (1974). A predictive approach to the random effect model. Biometrika, 61(1), 101-107.

Gore, P. A. (2006). Academic self-efficacy as a predictor of college outcomes: Two incremental validity studies. Journal of career assessment, 14(1), 92-115.

Guay, F., Chanal, J., Ratelle, C. F., Marsh, H. W., Larose, S., \& Boivin, M. (2010). Intrinsic, identified, and controlled types of motivation for school subjects in young elementary school children. British Journal of Educational Psychology, 80(4), 711-735.

Guthrie, J. T., \& Humenick, N. M. (2004). Motivating students to read: Evidence for classroom practices that increase reading motivation and achievement. In. P. McCardle \& V. Chhabra. (Eds.), The voice of evidence in reading research (pp. 329-354). Baltimore: Brookes Publishing.

Guthrie, J. T., Wigfield, A., Metsala, J. L., \& Cox, K. E. (1999). Motivational and cognitive predictors of text comprehension and reading amount. Scientific Studies of reading, 3(3), 231-256. 
Hair, J. J. F., Hult, G. T. M., Ringle, C. M., \& Sarstedt, M. (2014). A Primer on Partial Least Squares Structural Equation Modelling ( $2^{\text {nd }}$ Ed.). Thousand Oaks, CA: SAGE.

Hair, J. J. F., Hult, G. T. M., Ringle, C., \& Sarstedt, M. (2013). A primer on partial least squares structural equation modeling (PLS-SEM). : Sage Publications.

Hair, J. J. F., Ringle, C. M., \& Sarstedt, M. (2011). PLS-SEM: Indeed a silver bullet. Journal of Marketing theory and Practice, 19(2), 139-152.

Hair, J. J. F., Sarstedt, M., Ringle, C. M., \& Mena, J. A. (2012). An assessment of the use of partial least squares structural equation modeling in marketing research. Journal of the Academy of Marketing Science, 40(3), 414-433.

Heydarei, A., \& Daneshi, R. (2015). An Investigation on the Relationship of Family Emotional Climate, Personal-Social Adjustment and Achievement Motivation with Academic Achievement and Motivation among Third Grade High School Male Students of Ahvaz. Journal of Applied Linguistics and Language Learning, 1(1), 6-13. Hommes, M. A., \& Van der Molen, H. T. (2012). Effects of a Self-instruction Communication Skills Training on Skills, Self-efficacy, Motivation, and Transfer. European Journal of Open, Distance and E-learning, 15(1), 1-11.

Hulland, J. (1999). Use of partial least squares (PLS) in strategic management research: A review of four recent studies. Strategic Management Journal, 20(2), 195-204.

Jackson, D. (2013). Student perceptions of the importance of employability skill provision in business undergraduate programs. Journal of Education for Business, 88(5), 271-279.

Jackson, D. (2015). Employability skill development in work-integrated learning: Barriers and best practice. Studies in Higher Education, 40(2), 350-367.

Jackson, D., \& Chapman, E. (2012). Non-technical competencies in undergraduate business degree programs: Australian and UK perspectives. Studies in Higher Education, 37(5), 541-567.

Jackson, D., \& Wilton, N. (2016). Developing career management competencies among undergraduates and the role of work-integrated learning. Teaching in Higher Education 21(3), 266-286.

Kato, T., \& Hirose, Y. (2008). Three-Dimensional Evaluation of Technical Cooperative Education Programs for a Challenging Higher Education. Retrieved February 20, 2016, from http://www.waceinc.org/papers/vancouver/Japan/Kato,\%20Hirose.pdf.

Kember, D., Hong, C., \& Ho, A. (2008). Characterizing the motivational orientation of students in higher education: A naturalistic study in three Hong Kong universities. British Journal of Educational Psychology, 78(2), 313-329.

Khalid, N., Hamid, N. A. A., Sailin, R., Othman, N., Awang, A. H., \& Nor, M. F. M. (2014). Importance of Soft Skills for Industrial Training Program: Employers' Perspective. Asian Journal of Social Sciences \& Humanities, 3(4), 10-18.

Kickul, J., Gundry, L. K., Barbosa, S. D., \& Whitcanack, L. (2009). Intuition versus analysis? Testing differential models of cognitive style on entrepreneurial selfefficacy and the new venture creation process. Entrepreneurship Theory and Practice, 33(2), 439-453.

Komarraju, M., Karau, S. J., \& Ramayah, T. (2007). Cross-Cultural Differences in the Academic Motivation of University Students in Malaysia and the United States. North American Journal of Psychology, 9(2), 275-292.

Lareau, A., \& Weininger, E. B. (2003). Cultural capital in educational research: A critical assessment. Theory and society, 32(5-6), 567-606. 
Lin, D., Wong, K. K., \& McBride-Chang, C. (2012). Reading motivation and reading comprehension in Chinese and English among bilingual students. Reading and Writing, 25(3), 717-737.

Linnenbrink, E. A., \& Pintrich, P. R. (2002). Motivation as an enabler for academic success. School Psychology Review, 31(3), 313-327.

Litchfield, A., Frawley, J., \& Nettleton, S. (2010). Contextualising and integrating into the curriculum the learning and teaching of work-ready professional graduate attributes. Higher Education Research \& Development, 29(5), 519-534.

Lizzio, A., \& Wilson, K. (2004). Action learning in higher education: An investigation of its potential to develop professional capability. Studies in Higher Education, 29(4), 469-488.

Lumsden, L. S. (1994). Student Motivation To Learn. Eugene, Oregon: ERIC Clearinghouse on Educational Management, University of Oregon.

Lumsden, L. S. (1999). Student Motivation: Cultivating a Love of Learning. Eugene, Oregon: ERIC Clearinghouse on Educational Management, University of Oregon.

Maclellan, E. (2004). Evidence of Authentic Achievement: the extent of disciplined enquiry in student teachers' essay scripts. Australian Journal of Educational and Developmental Psychology, 4, 71-85.

Maelah, R., Muhammaddun Mohamed, Z., Ramli, R., \& Aman, A. (2014). Internship for accounting undergraduates: comparative insights from stakeholders. Education+ Training, 56(6), 482-502.

Martin, A., Rees, M., Edwards, M., \& Paku, L. K. (2012). An organization overview of pedagogical practice in work-integrated education. ia-Pacific Journal of Cooperative Education, 13(1), 23-37.

Martin, M. M., \& Myers, S. A. (2006). Students' communication traits and their out-ofclass communication with their instructors. Communication Research Reports, 23(4), 283-289.

McCombs, B. L. (1991). Motivation and lifelong learning. Educational psychologist, 26(2), 117-127.

McLachlan, S., \& Hagger, M. S. (2010). Effects of an autonomy-supportive intervention on tutor behaviors in a higher education context. Teaching and Teacher Education, 26(5), 1204-1210.

Ministry of Higher Education. (2013). Statistics of Higher Education of Malaysia. Malaysia: MOHE.

Mullen, J. (1997). Graduates deficient in 'soft'skills. People Management, 3(22), 18-.

Nagy, H., \& Smith, P. (2016). The Era of the Global Intern? Business Undergraduates' Perceptions of International Internships at a Foreign University in Vietnam. In P. Mandal \& J. Vong (Eds.), Smart Technologies for Smart Nations (pp. 91-108). Singapore: Springer.

Niemiec, C. P., \& Ryan, R. M. (2009). Autonomy, competence, and relatedness in the classroom Applying self-determination theory to educational practice. Theory and Research in Education, 7(2), 133-144.

Nikitina, L., \& Furuoka, F. (2012). Sharp focus on soft skills: a case study of Malaysian university students' educational expectations. Educational Research for Policy and Practice, 11(3), 207-224.

Oliver, B. (2015). Redefining graduate employability and work-integrated learning: Proposals for effective higher education in disrupted economies. Journal of Teaching and Learning for Graduate Employability, 6(1), 56-65. 
Page, C., Wilson, M., \& Kolb, D. (1993). Managerial competencies and New Zealand managers: On the inside, looking in. Auckland, New Zealand: University of Auckland.

Patton, W., \& McMahon, M. (2014). Career development and systems theory: Connecting theory and practice. The Netherlands: Sense Publishers.

Phelps, M., \& Creed, P. (1996). Self-efficacy as a factor in job training performance and occupational satisfaction for unemployed individuals. Journal of Applied Social Behaviour, 2(1), 44-63.

Powell, S., Tindal, I., \& Millwood, R. (2008). Personalized learning and the Ultraversity experience. Interactive Learning Environments, 16(1), 63-81.

Preacher, K. J., \& Hayes, A. F. (2008). Asymptotic and resampling strategies for assessing and comparing indirect effects in multiple mediator models. Behavior research methods, 40(3), 879-891.

Purdie, F., Ward, L. J., McAdie, T. M., King, N., \& Drysdale, M. (2013). Are workintegrated learning (WIL) students better equipped psychologically for work postgraduation than their non-work-integrated learning peers? Some initial findings from a UK university. Asia Pacific Journal of Co-operative Education, 14(2), 117-125.

Raelin, J. A., Bailey, M. B., Hamann, J., Pendleton, L. K., Raelin, J., Reisberg, R., \& Whitman, D. (2011). The effect of cooperative education on change in self-efficacy among undergraduate students: Introducing work self-efficacy. Journal of Cooperative Education and Internships, 45(2), 17-35.

Reay, D. (2004). 'It's all becoming a habitus': Beyond the habitual use of habitus in educational research. British journal of sociology of education, 25(4), 431-444.

Renganathan, S., Abdul Karim, Z. A., \& Chong, S. L. (2012). Students' perception of industrial internship programme. Education+ Training, 54(2/3), 180-191.

Ringle, C. M., Wende, S., \& Will, A. (2005). SmartPLS 2.0 (beta). Hamburg: SmartPLS. Retrieved Januart 21, 2016, from http://www.smartpls.com.

Rowe, A., Mackaway, J., \& Winchester-Seeto, T. (2012). But I thought you were doing that'-Clarifying the role of the host supervisor in experience-based learning. AsiaPacific Journal of Cooperative Education, 13(2), 115-134.

Rus, R. C., Yasin, R. M., Rubi, D. M., Nazri, A., Mamat, A. B., Hanapi, Z., \& Hasnan, K. A. (2015). From Training Institution to Workplace: Towards a Training Model in the Industrial Training Institutes. International Education Studies, 8(2), 60-69.

Ryan, R. M., \& Deci, E. L. (2000). Intrinsic and extrinsic motivations: Classic definitions and new directions. Contemporary Educational Psychology, 25(1), 54-67.

Saat, M. M., Yusoff, R. M., \& Panatik, S. A. (2014). The effect of industrial training on ethical awareness of final year students in a Malaysian public university. Asia Pacific Education Review, 15(1), 115-125.

Schiefele, U., Schaffner, E., Möller, J., \& Wigfield, A. (2012). Dimensions of reading motivation and their relation to reading behavior and competence. Reading Research Quarterly, 47(4), 427-463.

Schuetz, P. (2008). A theory-driven model of community college student engagement. Community College Journal of Research and Practice, 32(4-6), 305-324.

Schunk, D. H. (1991). Self-efficacy and academic motivation. Educational psychologist, 26(3-4), 207-231.

Smith, C., \& Worsfold, K. (2014). WIL curriculum design and student learning: a structural model of their effects on student satisfaction. Studies in Higher Education, 39(6), 1070-1084. 
Stone, M. (1974). Cross-validatory choice and assessment of statistical predictions. Journal of the royal statistical society. Series B (Methodological), 36(2), 111-147.

Subotnik, R. F., Olszewski-Kubilius, P., \& Worrell, F. C. (2011). Rethinking giftedness and gifted education a proposed direction forward based on psychological science. Psychological Science in the Public Interest, 12(1), 3-54.

Tran, L. T., \& Soejatminah, S. (2016). 'Get foot in the door': International students'perceptions of work integrated learning. British Journal of Educational Studies, 1-19.

Tsui, L. (2002). Fostering critical thinking through effective pedagogy: Evidence from four institutional case studies. The Journal of Higher Education, 73(6), 740-763.

Tuan, H. L., Chin, C. C., \& Shieh, S. H. (2005). The development of a questionnaire to measure students' motivation towards science learning. International Journal of Science Education, 27(6), 639-654.

Vatankhah, H., Daryabari, D., Ghadami, V., \& Naderifar, N. (2013). The Effectiveness of Communication Skills Training on Self-concept, Self-esteem and Assertiveness of Female Students in Guidance School in Rasht. Procedia-Social and Behavioral Sciences, 84, 885-889.

Wang, S.-L., \& Wu, P.-Y. (2008). The role of feedback and self-efficacy on web-based learning: The social cognitive perspective. Computers \& Education, 51(4), 1589-1598.

Weber, M. R., Finley, D. A., Crawford, A., \& Rivera, D. (2009). An exploratory study identifying soft skill competencies in entry-level managers. Tourism and Hospitality Research, 9(4), 353-361.

Webster, C. A. (2010). Increasing student motivation through teacher communication: Six essential skills every physical educator should master. Journal of Physical Education, Recreation \& Dance, 81(2), 29-39.

Williams, M., \& Burden, R. L. (1997). Psychology for language teachers. Cambridge: Cambridge University Press.

World Bank. (2014). Malaysia Economic Monitor: Boosting Trade Competitiveness. Washington, DC: World Bank.

Yap, M. (2015, October, 11). Let's soar and shine. The Star Online. Retrieved from http://www.thestar.com.my/news/education/2015/10/11/lets-soar-and-shine/

Yorra, M. L. (2014). Self-efficacy and self-esteem in third-year pharmacy students. American journal of pharmaceutical education, 78(7), 134-138.

Zajacova, A., Lynch, S. M., \& Espenshade, T. J. (2005). Self-efficacy, stress, and academic success in college. Research in higher education, 46(6), 677-706.

Zepke, N. (2011). Understanding teaching, motivation and external influences in student engagement: how can complexity thinking help? Research in Post-Compulsory Education, 16(1), 1-13.

Zhao, X., Lynch, J. G., \& Chen, Q. (2010). Reconsidering Baron and Kenny: Myths and truths about mediation analysis. Journal of consumer research, 37(2), 197-206. 